\title{
The Association of Cognitive Style of Unemployed Graduates in Lesotho to Entrepreneurial Intentions and Implications on Venture Start-Ups
}

\author{
Dr. Motšelisi C. Mokhethi \\ B.Ed. MBA. PhD Entrepreneurship \\ National University of Lesotho \\ Lesotho \\ Dr. Regina M. Thetsane \\ B.Ed. MBA. PhD Business Admin \\ National University of Lesotho \\ Lesotho
}

\begin{abstract}
The study aims to determine the association of cognitive style of unemployed graduates in Lesotho to entrepreneurial intentions and implications on venture start-ups. Data was collected from 276 graduates through a non-probability convenience sampling and attained 81.5 percent response rate. The instrument satisfied validity and reliability tests. The results found no statistical relationship between unemployed graduates' entrepreneurial intensions and cognitive thinking styles. However, there was significant positive relationship between self-efficacy and analytical thinking and a significant positive relationship between self-efficacy and entrepreneurial intentions suggesting a mediating role of self-efficacy, mediating analytical thinking and entrepreneurial intentions of unemployed graduates in Lesotho. The results portray that unemployed graduates in Lesotho are effective at implementation stages of the venture creation and not start-ups.
\end{abstract}

Keywords: Analytical thinking, Cognitive styles, Entrepreneurial intentions, Intuitive thinking, Venture start-ups

\section{Introduction}

There is increasing number of unemployed people due to lack of jobs (Aaijaz \& Ibrahim, 2013). Idogho and Augustine (2011) indicate that African countries are characterized by growing populations and a general decrease in formal employment. It is observed that Lesotho is no exception with regard to a significant number of new job seekers as unemployment rate averaged 25.3 percent with youth category defined as persons aged between 15 and 35 years being hard hit by the scourge where unemployment ranges between 30 and 33 percent (UNDP, 2012; Shale, 2013; UNDP, 2017). According to Aaijaz \& Ibrahim (2013) and Ekpoh and Edet (2011) university graduates are not safe from the problem of unemployment as the period between graduation and employment dates are increasingly becoming longer. According to Ridha, Wahyu, B and Wahyau, B.P (2017) on yearly basis colleges inject graduates into the labour market and due to lack of employment opportunities the positive contribution of colleges translates into the increase in unemployment. Entrepreneurship is advanced as one of the means to combat the challenge of unemployment, because it generates economic growth and employment (Aaijaz \& Ibrahim, 2013; Azila-Gbettor \& Harrison, 2013; Radipere, 2012; Idogho \& Augustine, 2011; Buttar, 2015; Rauch \& Hulsink, 2015). The entrepreneurial activity according to Atiase, Mahnood, Wang, and Botchie (2017) and Ali, Rashid and Khan (2014) takes place in Micro, Small, and Medium Enterprises (MSMEs) in most African economies. For instance, the authors' note that in Ghana MSMEs accounted for 92 percent of all businesses, provided 85 percent of all manufacturing jobs and generated 70 percent of GDP while in South Africa MSMEs accounted for 91 percent of all businesses, provide 61 percent of all employment and generated between 52 and 57 percent of GDP. In most developing countries, however, entrepreneurial activity by women and youth still takes place outside the formal sectors resulting in a minimal contribution to economic growth and this call for strategies that would promote the inclusion of women and youth entrepreneurs to be effective actor's in business (Zhan, 2014).

Entrepreneurs play an important role in the wealth creation of today's society as they are the center of new venture creation and are individuals who capitalize intellectual and physical assets to transform unique opportunities into new ventures (Zhang, Wang \& Owen 2015; Campo, 2011). According to Baron (2004), it is illogical to attempt to understand the entrepreneurial process without considering entrepreneurs as they are like "yeast" in the preparation of bread. 
The origin of entrepreneurial research meant to understand entrepreneurship variance focused on identifying the personality characteristics or traits that distinguishes entrepreneurs from the general population. The traits approach resulted in a modest success (Baron, 1998) as it only acknowledged the entrepreneur's contribution as a person but failed to isolate unique characteristics common to all entrepreneurs as different studies identified different characteristics. For example, McClelland (1961) identified need for achievement; Smith (2000) discovered passion, while Hatch (2000) identified what he called "entrepreneurial spirit" which encompasses elements such need for success and decisiveness. In particular, the traits approach failed to answer convincingly one of the important questions of why some people and not others are able to discover and exploit opportunities and create business ventures (Mitchell et al, 2002; Baron, 1998).

Despite the limitations revealed in the use of traits approach, still confirmed that entrepreneurs are members of the homogeneous group that are unique (Mtichell et al (2002) hence why cognitive approach emerged that focuses on the ways in which entrepreneurs and others think (Mitchell et al, 2002; Baron, 1998\& 2004; Sánchez, Carbollo\& Gutiérrez, 2011).According to Mitchell et al (2007), beneath the questions that give rise to the study of entrepreneurial cognition lays an underlying assumption that entrepreneurship concerns itself with distinctive ways of thinking and behaving within the context of new value creation. It is the purpose of this study to establish through an assessment of cognitive styles and entrepreneurial intentions whether unemployed graduates in Lesotho are potential entrepreneurs. The study adopts the cognition approach, specifically the cognitive/thinking style as little is known about the relationship between cognition and entrepreneurial intentions (Sánchez, et al 2011). Specifically, the study is designed to provide answers to the following research questions:

1. Are cognitive styles of unemployed graduates in Lesotho related to entrepreneurial intentions?

2. Is there a bearing of the cognitive styles of unemployed graduates in Lesotho to venture start-ups?

\section{Theoretical Framework}

Neisser (1967) in Posner and Bourke (1992) defines cognition as the mental processes that converts stimuli in the environment into useful information, select and store the useful information, which is retrieved and used when necessary while Mitchell et al. (2002) explain entrepreneurial cognitions as the knowledge maps thatan entrepreneur relies on in evaluating business opportunities and determining appropriate business start-up and growth actions. Cognitive approach is concerned with the entrepreneur's preferred way of gathering, processing and evaluating information (Allinson, Chell\& Hayes, 2000 in Keh, Foo, Lim, 2002)that differs from that of non-entrepreneurs (Sánchez et al, 2011).

According to Sánchez et al, (2011) cognitive literature is divided into two main lines, namely cognitive structures and cognitive processes. Cognitive structures represent knowledge maps that entrepreneurs rely onfor identification, evaluating and selecting among various business opportunities and in the establishment and growth of businesses, while cognitive processes relate to the way in which an individual gain, use and process information which will affect the way they think, say or do things. As the decision to become an entrepreneur is taken willingly and intentionally (Krueger, 2000), it is of interest to researchers to determine how that decision is taken.

One of the most influential models with respect to entrepreneurial cognitions explaining why people choose to be entrepreneurs is the entrepreneurial intentions model (Elfving, Brännback \& Carsrud, 2009). In fact, Bird (1988) regards entrepreneurs' intentions as important underpinnings of new venture development. Entrepreneurial intentions, is a measure that has been used as a reliable predictor of whether an individual is likely to actually become an entrepreneur (Mueller, Zapkau \& Schwens, 2014; Kickul, Gungry, Barbosa, \&Whitcanack 2009; McGee, Peterson, Mueller \& Sequeira, 2009; Zhang et al, 2015; Sánchez, n.d).

The entrepreneurial intentions model assumes that intentions precede entrepreneurship behavior while intentions are influenced by other factors (Ranuch \& Hulsink, 2015). The three widely used models are the Theory of Planned Behavior (TPB) (Ajzen, 1991), Entrepreneurial Event Theory (EET) (Ngugi,Gakura, Waithaka, Kiwara, 2012), and Entrepreneurial Intentionality (original-see Figure 2) (Bird, 1988:444; Rai\& Prasad, 2017). The 1988 model of Bird has been revised according to Boyd and Vozikis (1994) to incorporate the concept of self-efficacy as a mediator between analytical and rational thinking and entrepreneurial intentions as well as a mediating factor between entrepreneurial intentions and entrepreneurial action (see Figure 1). The study will be guided by the revised 1988 entrepreneurial intentionality model of Bird. 
Figure 1: A revised Model of Bird's (1988) contexts of Entrepreneurial Intentionality

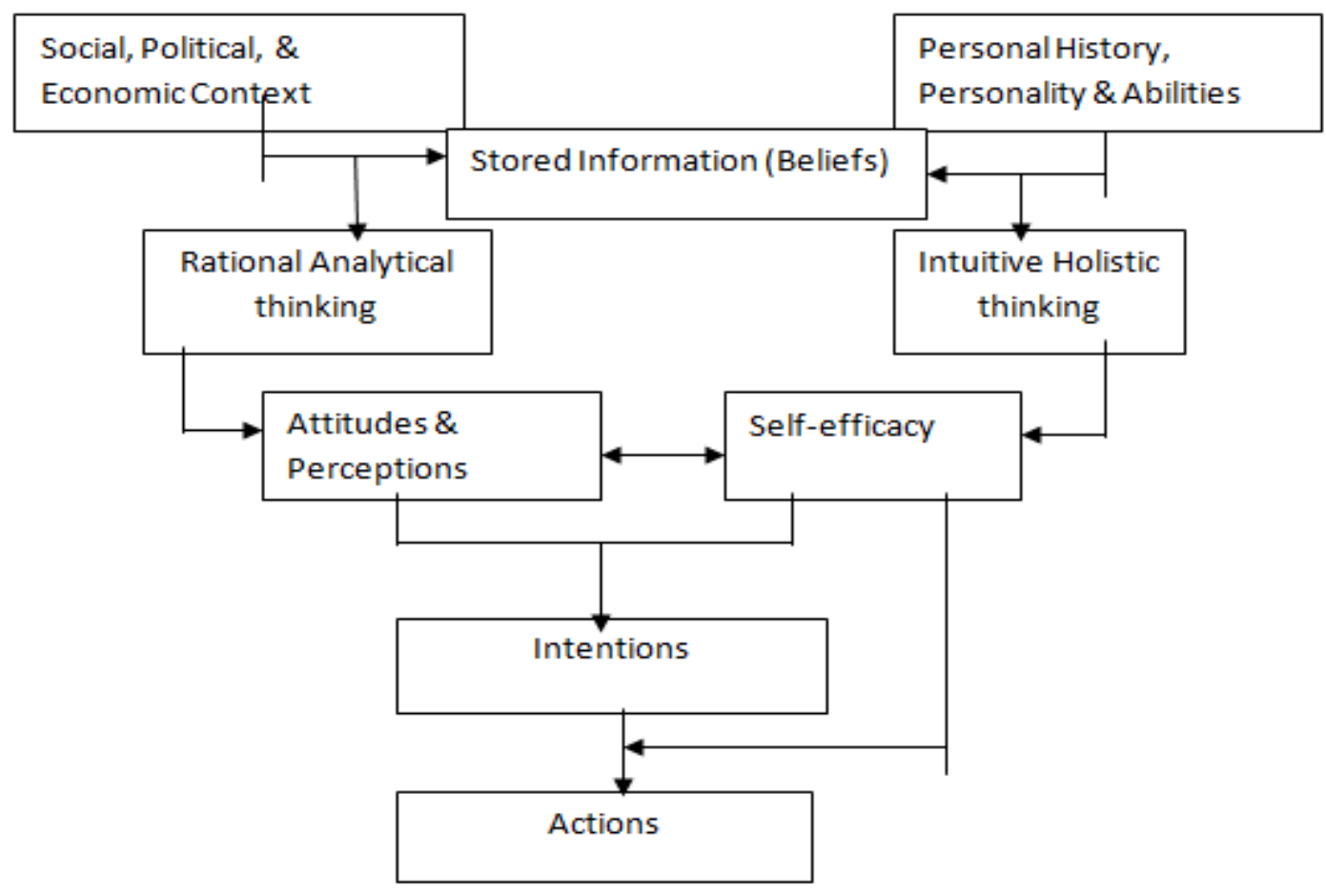

Source: Boyd \&Vozikis (1994:69).

Figure 2: A Model of Bird's (1988) contexts of Entrepreneurial Intentionality

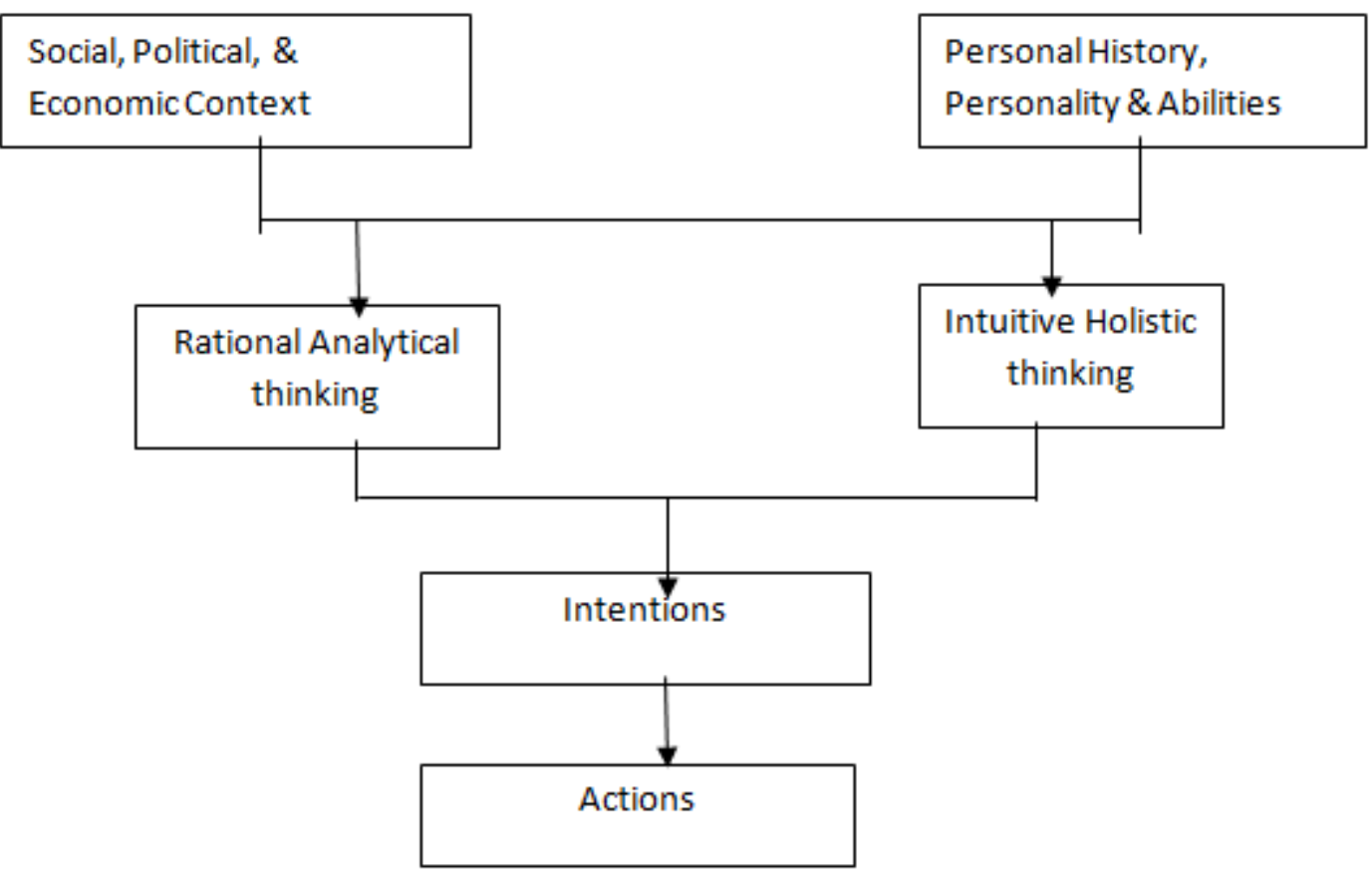

Source: Rai \& Prasad (2017:3). 


\section{Literature review}

Cognitive style is one of the cognitive aspects that provide a basis for identifying those individuals who have the potential to become successful entrepreneurs (Armstrong \&Hird, 2009) as it fosters an individual's self-belief in one's ability to conduct the task of entrepreneurship successfully (Kickulet al,2009).

Kickulet al (2009) defines cognitive style as an individual's preferred and habitual approach to organizing, representing and processing information, while Dutta and Thornhill (2012) contend that cognitive style is the way individuals process, thinks, solves problems, learns, takes decision and relate to others.

Cognitive styles of entrepreneurs differ from those of non-entrepreneurs. According to Lindblom, Olkkonen and Mitronen (2008), entrepreneurs are regarded as creative, informal and intuitive as opposed to formal, sequential and structured. Some studies categories entrepreneurs as either analytical or intuitive (Dutta \& Thornhill, 2009; Armstrong \&Hird, 2009).

"An analytic individual is risk averse, relies more on prevailing norms and framework, has higher need for conformity, and prefers to adopt an incremental approach to problem-solving and decision making. In contrast, Intuitive individual isless risk averse, is interested inbreaking and/or going beyond prevailing norms and frameworks, has less need for conformance, and prefers to adopt a more quantum approach to problem-solving and decision-making" (Dutta\&Thornhill, 2008 in Dutta\&Thornhill, 2009:153).

On the whole, the cognitive style is regarded as bipolar and according to Armstrong \&Hird (2009), everyone can be located on the continuum. Kickul et al's (2009) findings reveal that individuals with different cognitive styles are effective in different phases/activities of venture creation. According to the authors, an intuitive cognitive style may be useful in the searching stage (i.e. opportunity identification) of the new venture creation process, while an individual with the analytical cognitive style may display competency in judging and assessing information and choosing actions to implement.

According to Zhao, Seibert and Hills (2005), individuals choose to become entrepreneurs, that is, formulate entrepreneurial intentions, because they are high on entrepreneurial self-efficacy. Zhao et al (2005) is in agreement with the 1988 model of Bird as revised (see Figure 1) that self-efficacy has a mediating role to entrepreneurial intentions with other factors. In the 1988 Bird model self-efficacy mediates cognitive style and entrepreneurial intentions.

Self-efficacy refersto an individual's confidence in his/herability to perform entrepreneurial roles and activities successfully (Bandura, 1986). Thus, research on self-efficacy has been a useful construct distinguishing individuals that are regarded as entrepreneurs from those that are non-entrepreneurs (Chen, Greene \& Crick, 1998; Markman, Balkin\& Baron, 2005).It is noted that individuals with high levels of entrepreneurial self-efficacy perceive more opportunities than those who have low levels of entrepreneurial self-efficacy who regard the same situation to have more costs and greater risks (Cooper \& Lucas, 2005; Vecchio, 2003).Chen et al. (1998) is in agreement that entrepreneurial selfefficacy correlates with the intention of owning a business as individuals who have confidence in their ability to perform entrepreneurial roles and activities will be more prone to implementing such behavior than those that are less confident.

There are contracting findings regarding the influence of cognitive styles on entrepreneurial intentions. Kautonen, Gelderen and Fink (2013) define intention as a person's readiness to perform a given behavior. Mueller et al (2014) define entrepreneurial intention as one's commitment towards starting a business. The authors indicate that entrepreneurial intention precedes entrepreneurial behavior, which, refers to an individual's actual founding of a new firm. According to Zhang et al (2015), examining intentions is a meaningful approach to studying actual entrepreneurial behavior.

Kickul et al (2009) determined that cognitive style influences entrepreneurial intentions through self-efficacy. The authors indicate that different styles build different self-efficacy resulting in individuals who possess unequal selfefficacy in all the tasks, hence would be effective in different phases/activities of the venture process. On the other hand, Armstrong and Hird (2009) found a correlation between respondents' cognitive styles and their entrepreneurial drive. The authors further determined that entrepreneurs are more intuitive and less analytic than non-entrepreneurs. In fact, the more intuitive the subjects were, the higher was their drive towards entrepreneurial behavior. The results of Armstrong and Hird (2009) suggest that intuition is a component trait of entrepreneurs irrespective of the stage of the venture process.

Marjana, P.B, Ana and Marjana, M (2018) using the theory of planned behavior expanded by incorporating innovative cognitive style, as defined is similar to intuitive cognitive style, showed a positive influence on entrepreneurial intentions but when innovative cognitive style was taken as the only explanatory aspect the results were positive but weak. 
Barbosa, Gerhardt and Kickul's (2007) finding produced mixed results regarding the influence of cognitive style and entrepreneurial intentions as well as self-efficacy. The author concluded that cognitive style alone is not a strong determinant of entrepreneurial intentions however suggested need for more research as some findings could not be explained.

Based on the literature review, the following research hypotheses were formulated:

$H_{1 o}$ : The entrepreneurial intentions of unemployed graduates in Lesotho will not be positively related to intuitive cognitive style

$H_{l a:}$ The entrepreneurial intentions of unemployed graduates in Lesotho will be positively related to intuitive cognitive style

$H_{2 o:}$ The entrepreneurial intentions of unemployed graduates in Lesotho will not be positively related to analytical cognitive style

$H_{2 a}$ : The entrepreneurial intentions of unemployed graduates in Lesotho will be positively related to analytical cognitive style

$H_{30:}$ Self-efficacy of unemployed graduates in Lesotho will not be positively related to intuitive cognitive style

$H_{3 a}$ : Self-efficacy of unemployed graduates in Lesotho will be positively related to intuitive cognitive style

$H_{40}$ : Self-efficacy of unemployed graduates in Lesotho will not be positively related to analytical cognitive style

$H_{4 a:} \quad$ Self-efficacy of unemployed graduates in Lesotho will be positively related to analytical cognitive style

\section{Methodology}

A non-probability convenience sampling was used where unemployed graduates that were undergoing training for possible engagement to conduct a national census were given questionnaires to complete. There were a total of 1300 trainees placed in all the ten districts of the country. Sekaran and Bougie's (2013) table of sample size was used and a sample of 297 for the population size of 1300 was adopted. The four centers that were closer to reach that had 276 trainees were visited of which 225 agreed to complete the questionnaires translating into 81.5 percent response rate. The questionnaire developed from literature consisted of Section A focusing on demographic questions. Section B consisted of 20 items adopted from Krueger, Reiley and Carsrud (2000), Buttar (2015) and Lindblom et al, (2008), focusing on cognitive thinking styles, self-efficacy and entrepreneurial intention factors and were measured on a fivepoint Likert scale. Construct validity of the instrument was tested using an explanatory factor analysis, whilst Cronbach alpha was used to measure the internal reliability of the instrument.

\section{Results and discussion}

\subsection{Demographic analysis}

The majority of the respondents were females (57.6\%) while males constituted $42.4 \%$ of the respondents. Most of the respondents were in the age category 26-35 (69.8\%). For the education level, the majority of the respondents held a first degree (92.4\%) followed by postgraduate degree holders $(4.5 \%)$. Respondents with a qualification below a first degree were only 3.1 percent. The majority of the respondents graduated in the local institutions (87.9\%) leaving only $12.1 \%$ as graduates from institutions outside the country. In the current study only 10.8 percent of the respondents were employed. This confirms literature indicating that unemployment in Lesotho is high (UNDP, 2012; Shale, 2013; UNDP, 2017).

\subsection{Descriptive analysis}

The results showed that respondents scored a mean of $3.98(\mathrm{SD}=0.97)$ on entrepreneurial intentions meaning that unemployed graduates in Lesotho are potential entrepreneurs (see Table 1). The results further showed that there were significant gender differences in entrepreneurial intentions with males reflecting a higher mean than females as reflected in Table 2. Further, the results show the mean scores of self-efficacy, the average mean of the respondents was $4.14(\mathrm{SD}=0.76)$, this scale is above midpoint, which suggest that on average the respondents had fair confidence in their ability to start their own businesses. With regard to cognitive thinking, the average mean of the respondents on intuitive thinking was 3.76 ( $\mathrm{SD}=0.75$ ), while on the analytical thinking style, the respondents scored a mean of 4.02 $(\mathrm{SD}=0.69)$, this implies that there are respondents that are strong on intuitive and some on analytical thinking when it comes to decision making. But for the factor that merged intuitive and analytical thinking the respondents scored a mean of 2.70 ( $\mathrm{SD}=1.02)$, showing that on average candidates cannot be strong on both and this finding supports that cognitive thinking is bipolar (Armstrong \&Hird, 2009). 
Table 1: Descriptive statistics on entrepreneurial intensions, Self-efficacy, risk propensity and cognitive analytical style

\begin{tabular}{|l|l|l|l|}
\hline & Mean & Std. deviation & N \\
\hline Entrepreneurial intensions & 3.98 & .97156 & 219 \\
\hline Self-efficacy & 4.14 & .76076 & 224 \\
\hline Intuitive thinking style & 3.76 & .74927 & 220 \\
\hline Analytical style & 4.02 & .69489 & 220 \\
\hline Mixintuianaly & 2.70 & 1.01621 & 210 \\
\hline
\end{tabular}

Table 2: Test of significance between gender and entrepreneurial intensions,Self-efficacy and cognitive styles

\begin{tabular}{|l|l|l|l|l|}
\hline & Mean & & \\
\hline & Male & Female & Sig. (2-tailed) & df \\
\hline Entrepreneurial intensions & 4.14 & 3.87 & .35 & 216 \\
\hline Self-efficacy & 4.30 & 4.05 & .008 & 221 \\
\hline Intuitive thinking style & 3.87 & 3.67 & .047 & 218 \\
\hline Analytical style & 4.10 & 3.92 & .014 & 217 \\
\hline
\end{tabular}

\subsection{Factor analysis}

Exploratory factor analysis was conducted to determine construct validity of the instrument. From a list of twenty items three were eliminated leaving 17 items that grouped into five factors instead of four factors as suggested in literature (see Table 4). Factor one is named, self-efficacy (made up of 4 variables) factor two is analytical thinking (made up of four variables), while factor three is entrepreneurial intentions (made up of three variables), and factor four a mix of analytical and intuitive thinking (made up of three variables and lastly, factor five named intuitive thinking that is made up of threevariables. Factor four was named a mix of analytical and intuitive because the two variables namely "I do not collect information actively; I collect information only when advised to do so" were expected to test intuition thinking. On the other hand, the variable "the gathered information remains unanalyzed" was expected to test analytical thinking however factor analysis grouped them into one factor hence why the factor is named a mix analytical and intuitive thinking. Reliability of the variables used in this study was tested using Cronbach's Alpha, which tests the internal consistency of a scale. The variables have high internal consistency if Cronbach alpha is above 0.7 (Pietersen\&Maree 2016; Cohen, Manion\& Morrison, 2007) The Cronbach alpha results showed that the instrument used is reliable as shown in Table 3.

Table 3: Reliability of the scales

\begin{tabular}{|l|l|l|}
\hline Variables & Cronbach's Alpha & Number of items \\
\hline Entrepreneurial intention & 0.828 & 3 \\
\hline Self-efficacy & 0.858 & 4 \\
\hline Intuitive cognitive style & 0.745 & 3 \\
\hline Analytical cognitive style & 0.796 & 4 \\
\hline Mix intuitive/analytical style & 0.745 & 3 \\
\hline
\end{tabular}


Table 4: Factor Matrix with sorted rotated factor loadings

\begin{tabular}{|l|l|l|l|l|l|l|}
\hline Coding & Variables & $\begin{array}{l}\text { Factor } \\
\mathbf{1}\end{array}$ & $\begin{array}{l}\text { Factor } \\
\mathbf{2}\end{array}$ & $\begin{array}{l}\text { Factor } \\
\mathbf{3}\end{array}$ & $\begin{array}{l}\text { Factor } \\
\mathbf{4}\end{array}$ & $\begin{array}{l}\text { Factor } \\
\mathbf{5}\end{array}$ \\
\hline 10.10 & $\begin{array}{l}\text { I have the confidence that I can assemble resources to } \\
\text { realize the venture }\end{array}$ & $\mathbf{. 8 2 7}$ & .067 & .161 & .159 & .100 \\
\hline 10.9 & $\begin{array}{l}\text { I have the confidence that I can convert the idea into a } \\
\text { feasible business plan }\end{array}$ & $\mathbf{. 8 1 1}$ & .212 & .231 & -.006 & .150 \\
\hline 10.11 & $\begin{array}{l}\text { I have the confidence that I can lead and manage an } \\
\text { enterprise venture }\end{array}$ & $\mathbf{. 7 6 6}$ & .181 & .075 & .017 & .036 \\
\hline 10.8 & $\begin{array}{l}\text { I have confidence that I can search and identify business } \\
\text { opportunities }\end{array}$ & $\mathbf{. 7 3 1}$ & .063 & .261 & -.010 & .240 \\
\hline 10.19 & I am capable of analyzing collected information myself & .084 & $\mathbf{. 7 9 6}$ & -.005 & -.135 & .186 \\
\hline 10.17 & $\begin{array}{l}\text { My style of interpreting information is analytical and } \\
\text { rational }\end{array}$ & .166 & $\mathbf{. 7 6 8}$ & .090 & -.115 & .121 \\
\hline 10.18 & $\begin{array}{l}\text { I use a considerable amount of time to analyze gathered } \\
\text { information }\end{array}$ & .237 & $\mathbf{. 7 6 6}$ & -.001 & .090 & .122 \\
\hline 10.20 & $\begin{array}{l}\text { I use analyzed information extensively in my decision- } \\
\text { making }\end{array}$ & .018 & $\mathbf{. 6 5 6}$ & .173 & .083 & .214 \\
\hline 10.2 & $\begin{array}{l}\text { It is likely that I will start my own business in the } \\
\text { foreseeable future }\end{array}$ & .237 & .031 & $\mathbf{. 8 6 8}$ & .029 & .113 \\
\hline 10.1 & $\begin{array}{l}\text { There is high probability that I will start my own business } \\
\text { in the next 5 years }\end{array}$ & .282 & -.005 & $\mathbf{. 7 9 6}$ & .040 & .110 \\
\hline 10.3 & Is likely that I will start my own business on full-time bases & .122 & .141 & $\mathbf{. 7 8 1}$ & .129 & .057 \\
\hline 10.16 & I collect information only when advised to do so & -.030 & -.057 & .071 & $\mathbf{. 8 6 1}$ & .089 \\
\hline 10.15 & I do not collect information actively & .051 & -.191 & .018 & $\mathbf{. 7 9 7}$ & .148 \\
\hline 10.24 & The gathered information remains unanalyzed & .120 & .158 & .097 & $\mathbf{. 6 8 9}$ & .005 \\
\hline 10.13 & I gather information frequently & .164 & .187 & .102 & .113 & $\mathbf{. 8 0 4}$ \\
\hline 10.12 & $\begin{array}{l}\text { My style of information-gathering is systematic and well } \\
\text { planned }\end{array}$ & .166 & .343 & .024 & .026 & $\mathbf{. 7 3 0}$ \\
\hline 10.14 & I gather information on my own initiative & .124 & .176 & .159 & .107 & $\mathbf{. 6 9 4}$ \\
\hline & Eigenvalues & 5.097 & 2.474 & 2.152 & 1.253 & 1.126 \\
\hline $\mathbf{5 . 4}$
\end{tabular}

\subsection{Correlation results}

The association of cognitive style with entrepreneurial intention was first determined using a correlation. The correlation results show a significant positive relationship between entrepreneurial intentions of the respondents with intuitive thinking style and self-efficacy $(\mathrm{p}<0.01)$, and with analytical thinking and mix of intuitive and analytical factor $(\mathrm{p}<0.05)$ (see Table 5). The correlation results are consistent with other studies (Campo, 2011; Armstrong \&Hird, 2009) that showed a correlation between cognitive styles and entrepreneurial intentions.

\subsection{Regression results}

In addition, regression analysis was performed to establish the relationship between entrepreneurial intentions and cognitive factors while holding other factors constant that could have influenced correlation results. A linear regression analysis between the dependent variable (entrepreneurial intensions) and the independent variables (self-efficacy, analytical thinking, intuitive thinking and mix of intuitive and analytical thinking) was performed. The regression results found no statistical relationship between unemployed graduates' entrepreneurial intentions and intuitive and analytical thinking. Further, linear regression results reveal that there is a strong positive relationship between entrepreneurial intentions and self-efficacy $(\beta=.378, \mathrm{p}<0.01)$. As a result, hypotheses 1and 2 are accepted which reads,

$\mathrm{H}_{1 \mathrm{o}}$ : The entrepreneurial intentions of unemployed graduates in Lesotho will not be positively related to intuitive cognitive style $(\beta=.068, \mathrm{p}<0.458)$.

$\mathrm{H}_{20}$ : The entrepreneurial intentions of unemployed graduates in Lesotho will not be positively related to analytical cognitive style $(\beta=.008, \mathrm{p}<0.918)$.

The regression results are supported by literature indicating that cognitive styles are not related to entrepreneurial intensions (Kickul et al, 2014). However, the same authors indicate that cognitive styles relate to entrepreneurial intentions through self-efficacy. A linear regression analysis between the dependent variable (self-efficacy) and the independent variables (analytical thinking, intuitive thinking) was performed. The regression results found no statistical 
relationship between self-efficacy and intuitive thinking $(\beta=.003, p<0.963)$, while there was a strong positive relationship between self-efficacy and analytical thinking style $(\beta=.382, \mathrm{p}<0.01)$.

\section{Given the regression results Hypotheses 3 which reads:}

" $\mathrm{H}_{30}$ Self-efficacy of unemployed graduates in Lesotho will not be positively related to intuitive cognitive style is accepted while hypotheses 4 which reads:

" $\mathrm{H}_{40}$ Self-efficacy of unemployed graduates in Lesotho will not be positively related to analytical cognitive style is rejected.

The positive relationship between self-efficacy and analytical thinking style and between self-efficacy and entrepreneurial intentions suggest a mediating role of self-efficacy that mediates entrepreneurial intentions and cognitive style (in particular, analytical thinking), which is supported by findings from some studies (Zhao, et al, 2005;Barbosa etal, 2007).The findings show that some unemployed graduates in Lesotho showed a strong inclination towards analytical thinking. Analytical thinking style is considered effective atthe implementation stage of venture creation process (Kickul et al, 2009).

It is noted that graduates remain unemployed despite scoring high on entrepreneurial intentions. The results reflect an agreement with Kickul et al (2009)who suggest that individuals with inclination towards analytical style are good at the implementation stage of the venture creation process as such cannot start own business from scratch.

\section{Conclusion}

The study has brought to light that unemployed graduates in Lesotho have high entrepreneurial intentions and a strong believed that they can be able to perform the entrepreneurial task that is they have high self-efficacy. Further, the study shows that unemployed graduates in Lesotho are more inclined towards analytical cognitive thinking. The results suggest that the unemployed graduates in Lesotho are potential entrepreneurs but would be suited to act entrepreneurially when engaged at implementation stage of venture creation. The results therefore explain why unemployed graduates in Lesotho remain unemployed and are failing to start own business because start-ups are associated with intuitive thinking style.

The education policy makers should motivate review of curriculum in Lesotho universities and colleges which may also include the adoption of entrepreneurship education in order to equip graduates with intuitive thinking competences. Further, policy makers should introduce incentives for business to offer internship to graduates as experience also can stimulate intuitive thinking in graduates and in addition graduates can build capital that they can use to initiate business startups.

\section{References}

Aaijaz, N., \& Ibrahim, M.D.B. (2013). Influence of student's non-cognitive and cognitive traits on their proposed entrepreneurial ventures' initial set up decision. British Journal of Marketing Studies, 1(3), 1-15

Ajzen, I. (1991). The theory of planned behavior. Organizational Behavior \& Human Decision Processes, 50, 179-211

Ali, S., Rashid, H., \& Khan, M.A. (2014). The role of Small and Medium enterprises and poverty in Pakistan: An empirical analysis. Theoretical and Applied Economics, XXI (4),67-80

Armstrong, S.J., \&Hird, A. (2009). Cognitive style and entrepreneurial drive of new and mature business ownermanagers. Journal of Business and Psychology, 24(4),419-430

Atiase, V.M., Mahnood, S., Wang, Y., \&Botchie, D. (2017). Developing entrepreneurship in Africa: Investigating critical resource challenges. Journal of Small Business and Enterprise Development, Available online, https//doi.org/10.1108/JSBED-03-2017-0084, [Accessed: 2019-21-06].

Azila-Gbettor, E.M., \& Harrison, A.P. (2013). Entrepreneurship training and capacity building of Ghanaian Polytechnic graduates. International Review of Management and Marketing, 3(3),102-111

Bandura, A. (1986). Social foundations of thought and action: A social cognitive theory. Englewood Cliffs, NJ: Prentice Hall. xiii, 617 pages. 013815614X.

Barbosa, S.D., Gerhardt, M.W.,\&Kickul, J.R. (2007). The role of cognitive style and risk preference on entrepreneurial self-efficacy and entrepreneurial intentions. Journal of Leadership and Organizational Studies, 13(21),86-104

Baron, R.A. (1998). Cognitive mechanism in entrepreneurship: why and when entrepreneurs think differently than other people: Journal of Business Venturing, 13(4),275-294

Baron, R.A. (2004). The cognitive perspective: A valuable tool for answering entrepreneurship's basic "why" questions: Journal of Business Venturing, 19(2),221-225

Bird, B. (1988). Implementing entrepreneurial ideas: The case of intention. The Academy of Management Review, $13(3), 442-453$ 
Boyd, N.G., \&Vozikis, G.S. (1994). The influence of self-efficacy on the development of entrepreneurial intentions and actions. Entrepreneurship Theory and Practice, 18(1),63-77

Buttar, M.H. (2015). Formation of Entrepreneurial Career Intentions: The Role of Sociocognitive Factors. Journal of Employment Counseling 52(1),2-17.

Campo, J.L. (2011). Analysis of the influence of self-efficacy on entrepreneurial intentions, Prospect, 9(2),14-21

Chen, C.C., Greene, P.G., \& Crick, A. (1998). Does entrepreneurial self-efficacy distinguish entrepreneurs from managers? Journal of Business Venturing, 13(4),298-316

Cohen, L., Manion, L., \& Morrison, K. (2007). Research Methods in Education(6 ${ }^{\text {th }}$ ed.) USA\& Canada:Routlege

Cooper, S.Y., \& Lucas, W. (2005). Enhancing self-efficacy for entrepreneurship and innovation: an educational approach. University of Strathclyde, UK:Hunter Centre for Entrepreneurship, Available online: http://www.researchgate.net>publication, [Accessed: 2019-01-30].

Dutta, K.D., \&Thornhill, S. (2012). Venture Cognitive logic, Entrepreneurial Cognitive Style and Growth Intentions: A Conceptual Model and an Explanatory Field Study, De Cruyter. 4(2),147-166.

Ekpoh, U.I., \&Edet, A.O. (2011). Entrepreneurship Education and career intentions of tertiary education students in AlwaIbom and Cross River States, Nigeria, International Education Studies, 4(1),172-178

Elfving, J., Brännback, M., \&Carsrud, A. (2009). Towards a contextual model of entrepreneurial intentions. International Studies in Entrepreneurship,[Online]: Available from: http://www.cfses.com. [Accessed: 201606-18]

Hatch, J. (2000). What is the stuff of an entrepreneur? Business Journal, Nov/Dec. 65(2),68

Idogho, P., \& Augustine, B.A.E. (2011). Entrepreneurship education and small-scale business skill development among students of Auchi Polytechnic Edo State Nigeria. International Journal of Business and Management, 6(3),284-288 Available on line http://www.ccsenet.org/ijbm. [Accessed: 2019-01-28].

Kautonen, T., van Gelderen, M., \& Fink, M. (2013). Robustness of the theory of planned behavior in predicting entrepreneurial intentions and actions. Entrepreneurship Theory and Practice, 39(3),655-674

Key, H.T., Foo, M.D.,\&Lim, B.C. (2002). Opportunity Evaluation under Risky Conditions: The Cognitive Processes of Entrepreneurs. Entrepreneurship Theory and Practice, 27(2), 125-148.

Kickul, J., Gungry, K.L., Barbosa, D.S., \&Whitcanack.(2009). Intuition versus Analysis: testing Differential Models of Cognitive Style on Entrepreneurial Self-Efficacy and the New Venture Creation Process. Entrepreneurship Theory and Practice, 33(2), 439-453.

Krueger, Jr, N.F., Reiley, M.D., \&Carsrud, A.L. (2000). Entrepreneurial Intentions: A competing models Approach. Journal of Business Venturing, 15(5/6),411-432

Kruger, N.F. (2000). The cognitive infrastructure of opportunity emergence. Entrepreneurship Theory and Practice, 24(3),5-24

Lindblom, A., Olkkonen, R., \&Mitronen, L. (2008). Cognitive Styles of Contractually Integrated Retail Entrepreneurs: A survey Study. International Journal of Retail and Distribution Management, 36(6),1-17

Marjana, P.B., Ana, A., \&Marjana, M. (2018). Examining determinants of entrepreneurial intentions in Slovenia: applying the theory of planned behaviour and an innovative cognitive style. Economic researchEkonomskaIstraživanja, 31(1),1453-1471. Available online http://www.tandfonline.com/loi/rero20 [Accessed: 2019-01-28].

Markman, D.G., Balkin, D.B., \& Baron, A.R. (2002). Inventors and new venture formation: the effects of general selfefficacy and regretful thinking. Entrepreneurship Theory and Practice, 27(2), 149-165.

McClleland, D.C. (1961). The achieving society.London:D.vanNostrand Company, Inc.

McGee, J.E., Peterson, M., Mueller, S.L.,\&Sequeira, J.M. (2009). Entrepreneurial self-efficacy: refining the measure. Entrepreneurship Theory and Practice. 33(4), 965-988

Mitchell, R.K., Busenitz, L.W., Bird, B., Gaglio, C.M., McMullen, J.S., Morse., \&E.A. Smith, J.B. (2007). The central question in entrepreneurial cognition research 2007. Entrepreneurship Theory and Practice. 31(1), 1-27

Mitchell, R.K., Smith, J.B., Morse, E.A., Seawright, K.W., Peredo, A.M.,\&McKenzie, B. (2002). Toward a theory of entrepreneurial cognition: Rethinking the people side of entrepreneurship research. Entrepreneurship Theory and Practice, 27(2), 93-104

Mueller, J., Zapkau, F., \&Schwens, C. (2014). Impact of prior entrepreneurial exposure on entrepreneurial intentioncross-cultural evidence. Journal of Enterprising Culture,22(3),251-282.

Ngugi, J.K., Gakura, R.W., Waithaka, S.M., \&Kiwara, A.N. (2012). Application of Shapero's model in explaining entrepreneurial intentions among university students in Kenya.International Journal of Business and Social Research, 2(4), 125-148

Pietersen, J., \&Maree, K. (2016). Standardisation of a questionnaire. In K. Maree (Ed), First steps in research. Pretoria: Van Schaik. 237-247. 
Posner, M., Bourke, P. A., (1992). Cognitive Psychology. The American Journal of Psychology, 105(4),621-626.

Radipere, S. (2012). South African university entrepreneurship education, African Journal of Business Management, 6(44), 11015-11022

Rai, R.V., \& Prasad, A. (2017). A review on intention models for predicting entrepreneurial behaviour. Journal of Entrepreneurship Education, 20(2),1-9

Rauch, A., \&Hulsink, W. (2015). Putting entrepreneurship education where the intention to act lies: an investigation into the impact of entrepreneurship education on entrepreneurial behavior. Academy of Management Learning \& Education 14(2), 187-204

Ridha, R.N., Wahyu, B., \&Wahyu, B.P. (2017). Entrepreneurship intention in agricultural sector of young generation in Indonesia, Asia Pacific Journal of Innovation and Entrepreneurship, 11(1),76-89

Sánchez, C.J., Carballo, T., \& Gutiérrez, A. (2011). The entrepreneur from a cognitive approach.Psicothema, 23(3), 433-438

Sánchez, C.J., (n.d). The entrepreneurial intentions: The role of the cognitive variables.Available online, http://www.intechopen.com : [Accessed: 2018-12-17]. 27-30.

Sekaran, U., \& Bougie, R. (2013). Research methods for business: a skill-building approach. $\left(6^{\text {th }}\right.$ ed). United Kingdom: John Wiley \& Sons Ltd.

Shale, M. (2013). Unemployment biggest problem for Basotho, who also endorse illegal migration to get jobs.Afro Barometer Briefing Paper no.119.Available online, https://www.afrobarometer.org/sites/default/files/publications/.../afrobriefno119.pdf.[Accessed: 2019-07-05].

Smith, P. (2000). Pursuing passion. Management, 47(11), 94-97

UNDP. (2012). Lesotho Youth Empowerment Survey. Available online, https://www.undp.org/content/dam/lesotho/.../Lesotho\%20Youth\%20ReportFinal.pdf?...[Accessed: 2019-0705].

UNDP. (2017). Lesotho Country Analysis, working document: Final draft. Available online, https://.www.undp.org/.../lesotho/.../Lesotho\%20CCA_Final\%20Draft_22\%20September\%20 [Accessed: 2019-07-05].

Vecchio, R.P. (2003). Entrepreneurship and leadership: common trends and common threads. Human Resources Management Review,13(2),303-327.

Zhan, J. (2014). Latest Developments in FDI and Entrepreneurship Trends and Policies. Investment, Enterprise and Development Commission Sixth Session, Division on Investment and Enterprise UNCTAD. http://UNCTAD.org/meetings/en/Presentation/Cii2004_Zhan01_en. [Accessed: 2015-02-09].

Zhang, P., Wang, D.D., \& Owen, C.L. (2015). A study of entrepreneurial intentions of university students, $D E$ GRUYTER, 5(1),61-82

Zhao, H., Seibert, S.E., \& Hills, G.E. (2005). The mediating role of self-efficacy in the development of entrepreneurial

\section{Appendix} intentions. Journal of Applied Psychology, 90(6),1265-127

Table 5: Correlation results

\begin{tabular}{|c|c|c|c|c|c|c|}
\hline & & Intentions & Self-efficacy & Intuitive & Analytical & $\begin{array}{l}\text { Mix } \\
\text { Intuianaly }\end{array}$ \\
\hline Intention & Sig (2-tailed) & & .000 & .000 & .017 & .025 \\
\hline \multirow[t]{3}{*}{ Self- efficacy } & Pearson correlation & $.426^{* *}$ & 1 & $.628^{* * *}$ & $.340^{* *}$ & .058 \\
\hline & Sig (2-tailed) & .000 & & .000 & .000 & .407 \\
\hline & $\mathrm{N}$ & 218 & 224 & 220 & 219 & 209 \\
\hline Intuitive & $\mathrm{N}$ & 214 & 220 & 220 & 216 & 206 \\
\hline \multirow[t]{3}{*}{ Analytical } & Pearson correlation & $.163^{*}$ & $.340^{* * *}$ & $.501^{* * *}$ & 1 & -.047 \\
\hline & Sig (2-tailed) & .017 & .000 & .000 & & .497 \\
\hline & $\mathrm{N}$ & 214 & 219 & 216 & 220 & 207 \\
\hline \multirow{2}{*}{$\begin{array}{l}\text { Mix } \\
\text { intuianaly }\end{array}$} & Pearson correlation & $.157^{*}$ & .058 & $.152 *$ & -.047 & 1 \\
\hline & Sig (2-tailed) & .025 & .407 & .029 & .497 & \\
\hline
\end{tabular}

** Correlation is significant at the 0.01 level (2-tailed)

*Correlation is significant at the 0.05 level (2-tailed) 